\title{
The Political Policy of Muaro Jambi Local Government and It's Impact on People's Welfare
}

\author{
Pahrudin $\mathrm{HM}^{1}$, Ratna Dewi ${ }^{2}$, etc \\ \{pahrudinhm@unja.ac.id ${ }^{1}$ \} \\ ${ }^{1}$ Faculty of Social and Political Sciences, Universitas Jambi, Jambi, Indonesia, ${ }^{2}$ Faculty of Law \\ Universitas Jambi, Jambi, Indonesia ${ }^{2}$
}

\begin{abstract}
After the implementation of decentralization policy in autonomy format, local government became the main locomotive of development in Indonesia. This is because the local government is assessed to have better knowledge about the needs and preferences of its citizens. The regional government in implementing regional autonomy is obliged to fulfill the regional needs in accordance with the established budget with the aim of improving the welfare of its people by improving the quality of life, developing democratic life, realizing justice and equity, improving basic education services, providing health care facilities and providing facilities social and public facilities. Therefore, development programs through a series of policies generated by the heads of regions are highly anticipated, so that the welfare of society that has been aspired in achieved. However, some studies have shown that decentralization in many parts of Indonesia is still not able to achieve the welfare of society with the various factors that cause it. This research was a qualitative approach with literature research conducted by reviewing development programs of Muaro Jambi and it is society's welfare data during 2015-2017. The study's results show that the level of community welfare in this area is not high because the poverty number still 17.520 people $(4.30 \%)$ and the unemployment rate is still 75,988 people $(5.40 \%)$. Therefore, the efforts of local governments through a series of development policies that can improve the welfare of the community must be improved.
\end{abstract}

Keywords: Decentralization, Local Government, Political Policy, Welfare.

\section{Introduction}

Research on the political impact of Muaro Jambi district government policy on people's welfare becomes interesting to do. This is because based on several reasons, namely: the first decentralization policy underlying the management of post-reform areas promises economic efficiency, program cost-effectiveness, accountability, increased resource mobilization, reduced disparities, increased political participation, and strengthening democracy and stability politics [1]. Secondly, through decentralization, local governments are perceived to have better knowledge of the needs and preferences of their people, the development process in the decentralization policy model should be more efficient than the centralized policy model in the framework of improving the welfare of local people [1]. Third, some studies show that decentralization in various parts of Indonesia is still not able to achieve the welfare of society as the main goal of its implementation with various factors that cause it [2], [3]. Fourth, based on data from BPS (2017), Muaro Jambi Regency has the second largest population after Kota 
Jambi (410,000 inhabitants) and the largest population density (77.04 inhabitants / km2) for the district category in Jambi Province, thus requiring significant local government a series of development policies that make people prosperous [4].

As it is known that regional autonomy that frames the policy of decentralization is massively rolled out after the reform movement marked by the collapse of New Order power in Indonesia, this policy guided Law Number 32 the Year 2004 on Regional Autonomy which in it states that the local government is the Governor, Regent, or Mayor and regional apparatus as elements of local government administrators. The regional government in implementing regional autonomy must fulfill the regional needs by the budget that has been set with the aim to improve the welfare of the community. In carrying out autonomy, the regions have obligations including improving the quality and life of the people, developing democratic life, realizing justice and equity, improving basic education services, providing health care facilities, and providing social facilities and decent public facilities.

The regional autonomy was chosen as a development approach in Indonesia after the New Order because it promised economic efficiency, cost-effectiveness, accountability, increased resource mobilization, reduced disparities, increased political participation and strengthening democracy and political stability [1]. Through decentralization, local governments play a greater role in development as they now have the authority and responsibility for community development in their jurisdictions. As local governments are perceived to have better knowledge of the needs and preferences of their citizens, the development process in the decentralization policy model should be more efficient than the centralized policy model regarding improving the welfare of local communities. This is because, in the decentralization policy, local governments can allocate resources better to meet the needs of the community. Thus, theoretically, as mentioned earlier that the decentralization policy model should be able to bring a better level of welfare than if the centralized (centralized) system.

Thus it can be said that local governments have a much greater opportunity to improve the welfare of society because of the diversion of various authorities that had previously become the 'domain' of the central government. The wide powers granted in the decentralization system are expected to make the region produce a variety of innovative regional development programs. Through a series of innovative development programs produced by local governments, it is hoped that the welfare of the people who become something rare in the past can become a reality.

\section{Methods}

This study uses a qualitative research approach to determine the level of a community's welfare of Muaro Jambi District related development programs that have been implemented. The type of research is literature research by reviewing data related to development programs in Muaro Jambi and the community's welfare in the last three years (2015-2017). Data were analyzed using qualitative data analysis [5].

\section{Results and Discussion}

\subsection{Political Concept of Policy}


As the party that submits the task of state management, the government is required to be able to present various development policies that can overcome the problems faced by the community. Along with the election of regional autonomy marked by the imposition of a decentralized system, most of the tasks and responsibilities of the central government have been transferred to local governments. The regional autonomy was chosen as a development approach in Indonesia after the New Order because it promised economic efficiency, costeffectiveness, accountability, increased resource mobilization, reduced disparities, increased political participation and strengthening democracy and political stability [1]. Through decentralization, local governments play a greater role in development as they now have the authority and responsibility for community development in their jurisdictions. As local governments are perceived to have better knowledge of the needs and preferences of their citizens, the development process in the decentralization policy model should be more efficient than the centralized policy model regarding improving the welfare of local communities. This is because, in the decentralization policy, local governments can allocate resources better to meet the needs of the community. Thus, theoretically, as mentioned earlier that the decentralization policy model should be able to bring a better level of welfare than if the centralized (centralized) system.

Local governments that already have wide authority in regional management in the regional autonomy system are expected to produce public policies in the form of development programs. Broadly public policy is often defined as' whatever the government chooses to do or not do [6]. It is further said that public policy is a government decision or decision to take an action which is considered to have a good impact on the lives of its citizens. Policies are essentially decisions that directly govern the management and distribution of natural, financial, and human resources in the public interest [7]. Public policy refers to terms or concepts to describe certain highly specific action options, such as in certain areas of the public utility sector.

\subsection{The Concept of Welfare}

Prosperous is the main vision of the presence of a country around the world, without exception Indonesia, as embodied in the Preamble to the 1945 Constitution. Achieving the welfare of people in various regions is the main objective also underlying the birth of desire implementation of regional autonomy after the roll of reform in Indonesia. The question is what is meant by the welfare? Is only limited to the income of the people related to the economy or also related to other areas.

The welfare of society, a term often used in academic terminology is social welfare, experiencing a shift in understanding and its use. Social welfare points to the conditions of good living, the fulfillment of the material need for life, the spiritual needs (not enough to admit religion but the real form of religion as respect for others), social needs such as orderly order, conflicts in life can be managed, security can be guaranteed, justice can be established where everyone has the same position before the law, reduces socio-economic disparities.

There are three categories of attainment of welfare, namely first, the extent to which social problems can be regulated. Second, the extent to which needs can be met and third, the extent to which opportunities to improve living standards can be obtained. All of these can be created in common life, whether at the family level, in community and society at large. On the other hand, the indicator can not be generalized because, in daily reality, the word social welfare has shifted its meaning, ie as a philanthropy (charity) activity, social service program, public assistance conducted by the government for the poor and neglected and social service programs of the organization social nature of a legal entity. When social welfare shifts from 
the well being to the social welfare service, public institutions are busy dealing with service programs. When the program is completed and implemented, finances can be accounted for; then it is overdone the work related to social welfare.

The concept of social welfare becomes specific and narrow, which becomes the claim of certain jobs of certain Ministries in Indonesia, as if this has become the affairs of the Ministry of Social Affairs, as stated in Law No. 11 on Social Welfare article 4 states that the State is responsible for the welfare social. In article 5, paragraph 2, the implementation of social welfare is prioritized on poverty, dislocation, disability, remoteness, social impairment (behavioral aberrations), disaster victims, victims of violence, exploitation, and discrimination.

Welfare pluralism also refers to the organization of social welfare by formal organizations that are not only limited to public organizations but also social and economic organizations. These are organizations of organizational social service providers, who often stand outside of the communities they serve. In general, the organization does not designate a long-standing community institution and is patterned within the community itself. In short, the formulation of prosperity is the dominance of the interests of social assistance services from outside the community served, while the community itself occupies a subordinate position in formulating whether or not he is prosperous. This kind of welfare becomes a welfare system solution by formal organizations, including the state [8].

The current reform measures are in line with the basic ideas of the Indonesian nation: being a sovereign, democratic, and just society, prosperous, prosperous and free from corruption (collusion, corruption, and nepotism). If the people of Indonesia with a high commitment to achieve the welfare of its people, then the nation of Indonesia will be respected by other nations. Thus, in the future, there will no longer be people who are abused by other nations. Therefore, a noble nation is a nation of character, and a nation of character is an independent nation, not a nation that always sells itself to foreign interests. By him, the Indonesian nation should not be a dwarf nation, which is always inferior in the presence of foreign nations. Indonesia has very capable human resources to manage natural resources for the benefit of the nation and state. Efforts to advance Indonesia's human resources minimal in the frame as below:

1. Education: is the most important way to educate the nation. With education, Indonesia will have human being superior, skilled, virtuous, and have spiritual strength and high motivation to build the nation.

2. Increasing the welfare of all Indonesian people, including clothing, food, and housing. The Central Statistics Agency (BPS) explained that the poverty measure is based on the number of calories a person eats, i.e., 2,100 calories. If consumption per day above the minimum calorie limit is not considered poor if below it is considered poor. When using the International measure means still very much the people of Indonesia who live below the poverty line.

3. The most important aspect of welfare is Health. If the health of the Indonesian Society is increased and maintained, the concentration in work, schooling, and activities is good, which in turn productivity increases. To increase the level of public health there are at least 4 things that must be immediately addressed by the government, namely:

a. Increased public health budget: in this way, public expenditures and costs will decline, as it turns into government subsidies, and then government-funded healthcare controls are focused on preventive or disease prevention actions.

b. In carrying out the role of government as a health regulator, it involves all elements, both government, corporate, individual, family, and society in general. 
c. Health insurance coverage (Health Insurance), it is time all layers of society have insurance and health insurance.

With this pattern, there is cross-subsidy in health handlers. It means that people who happen to be sick and in great need, will get subsidies from the society who are able and not sick. Insurance is a unity with the taxpayer program, so that people who have paid the tax, means automatically have obtained Health Insurance Guarantee, which taken optimally from the tax. If this is done well, it will have a significant positive impact on improving the health and well-being of many people, including doctors, health care workers, and the wider community - equitable health services for all Indonesian people to the rural level. The certainty of affordability of health services can touch all levels of society. If all of the above aspects are met then, of course, the quality of Indonesian society can increase. As expressed by Amartya Sen (2002), that welfare economics is a rational process towards releasing society from obstacles to progress. Social welfare can be measured from measures such as level of living, basic needs fulfillment, quality of life and human development. Furthermore, it is said that there is a tendency to prefer the capability approach in determining the standard of living, "the freedom or ability to achieve desirable" functioning" is more important than actual outcomes".

\subsection{Measurement of Welfare Level}

The Community Welfare Index as a composite value can show how much improvement the welfare of the community in an area has been achieved. The Public Welfare Index is very important as a basis for preparing future development planning especially human resources development in the region. For the assessment of community welfare index focused on three important elements as mandated by Minister of Home Affairs Regulation No. 54 of 2010 on Implementation of Government Regulation Number 8 the Year 2008 About Stages, Procedures, Formulation, Control and Evaluation of Implementation of Regional Development Plan, Attachment one is:

1. Focus on Welfare and Economic Equity (GDP growth, Inflation Rate, Per Capita GRDP, Gini Index, Equity Income, Poverty rate, Crime Numbers).

2. Community Welfare Focus (Education: Literacy Rate, School Average, Rough Participation Rate, Educational figures are resolved, Dropout Rate, Illiteracy, Pure Participation Rate. Health: Infant Survival Rate, Life Expectancy Rate, Percentage of Under-five Malnutrition, Length of Breastfeeding, Mortality rate (morbidity), Birth Helper. Land: Percentage of People with Land. Employment: Labor Force and NonLabor Force, Labor Force Participation Rate, Unemployment Rate, Business Field, Employment Status. The pattern of Consumption and Distribution of Spending: Average Expenditure Pattern per capita, Average expenditure per capita for food, and Average monthly expenditure per capita for non-food items.

\subsection{Community Welfare at Muaro Jambi District}

Based on the above explanation can be said that the level of community welfare of a region is closely related to the extent of political policy run by the local government running effectively. That is, if the vision and mission do the local government development programs in various fields, then certainly the level of welfare of the community will be good. It is because, in the era of regional autonomy, local governments can specifically implement development policies based on their potential to address existing problems. 
Muaro Jambi is one of the districts in Jambi Province which was established based on Law No. 54 of 1999 as the expansion area of Batang Hari District, officially the Government of Muaro Jambi District started on October 12, 1999. Central Government in Sengeti City as the capital city Muaro Jambi District with Office Center at Bukit Baling Sekernan District. Muaro Jambi District has a strategic geographical location located in the hinterland of Jambi City; this gives advantages for Muaro Jambi because this district has a big enough opportunity as a supplier area of Jambi city needs, such as marketing for agricultural products, fishery, industry and services (Pemkab Muaro Jambi, 2015). Overall, the area of Muaro Jambi District is $5,264 \mathrm{Km}^{2}$, with population up to 2017 of 410,337 people with an average growth of $2.8 \%$ per year and productive age (15-60 years) of 282,647 people or half of the total population [4].

For about 18 years of adopting regional autonomy, Muaro Jambi District has enjoyed the results of the system that was born of the reforms. This is achieved through development programs that have been proclaimed by some regents who have served in Muaro Jambi District after its formation in 1999. In the context of this study, to see how far regional autonomy can improve the welfare of the community, the focus of attention is only on the last 3 years (2015 -2017). There are development programs implemented by Muaro Jambi District Government, namely: Integration of livestock sector of cow and oil palm plantation, Increase of extension capacity, assistance of agricultural machine tools and production facilities, Construction of production road, improvement of farmer's knowledge and skills, Industrial investment processing and empowering farmers to master appropriate technology, empowerment and assistance as well as access to capital, development and development of community infrastructure and economic production centers, development and promotion of creative economy industries based on community and local commodities, urban agro-business development, unemployment, Provision of greater quota of labor of origin of Muaro Jambi, Program of enhancing development access and connectivity between regions of Muaro Jambi District, and Revitalization of Training Center (BLK).

Implementation of these policies finds its estimate by disseminating data on community welfare in Muaro Jambi District in several indicators. Economic growth has increased from year to year, as seen in 2015 amounted to $5.24 \%$ to $5.43 \%$ in 2016 . The same thing also surfaced with Gross Domestic Product (PDRB) in 2015 of IDR. 17,048,617.67 increased to IDR. $19,104,814.49$ in 2016 . The implication is targeted at the decrease of poverty number in 2015 by 18.320 people (4.63\%) to 17,520 people $(4.30 \%)$ in 2016 . On the education aspect, Illiteracy rate also decreased in the last two years, by 2016 by $1.37 \%$ to $1.25 \%$ in 2017 . On the other hand, the School Enrollment Rate has fluctuated, at the Elementary (SD) level in 2016 (99.16\%) increased to 99.66\% in 2017, the Junior High School (SMP) level of 2016 (98.87\%) decreased to $96.99 \%$ in 2017, while the High School (SMA) level of 2016 (74.98\%) increased to $77.77 \%$ in 2017 . The crime rate of 2016 increases as much as 431 cases compared to 2015 (172 cases). The Labor Force Participation rate is $61.13 \%$ in 2017 ; the unemployment rate is still at $5.40 \%$ or 75,988 people (2017) [4].

Thus it can be said that the development programs in Muaro Jambi District have a significant impact on people's welfare. It is indicated by the decrease in the poverty rate from year to year and the improvement of other public welfare indicators. However, the Muaro Jambi District Government still accuses some problems that must be sought to find solutions, such as poverty and unemployment rates are still relatively high. This effort may only be possible through a series of innovative-solutive development programs undertaken by the Muaro Jambi District Government in the next few years. Although the poverty rate is still below the national figure (about 10\%), but as an autonomous region, the Government of Maro Jambi District should continue to improve the development programs so that poverty can 
continue to be suppressed. The same is true of the still high unemployment rate which will certainly have implications on the income and welfare of the community.

\section{Conclusion}

Based on the above explanation can be concluded that Muaro Jambi District Government has development programs to improve people's welfare. These policies have an impact on people's lives as indicated by improvements in some welfare indicators. However, the Muaro Jambi District Government still has to improve innovative development programs-solutive because of the large poverty and unemployment rates.

\section{References}

[1] Bird, R., \& Vaillancourt, F. Fiscal Decentralization in Developing Countries. United Kingdom: Cambridge University Press, 1988.

[2] Hasjimzum. Yusnani. 'Model Demokrasi Dalam Peningkatan Kualitas Pelayanan (Studi Otonomi Daerah dalam Peningkatan Kesejahteraan Masyarakat Pasca Reformasi)' Jurnal Dinamika Hukum, Vol. 14, No. 3, September 2014.

[3] Tasrin, Krimiyati \& Wulandari, Putri. 'Kajian Pengaruh Kebijakan Desentralisasi Pada Peningkatan Kesejahteraan Masyarakat (Studi Kasus Kabupaten/Kota di Jawa Barat). Jurnal Borneo Administrator, Volume 8, No. 2, 2012.

[4] Badan Pusat Statistik Kabupaten Muaro Jambi. Statistik Kesejahteraan Kabupaten Muaro Jambi 2016-2017. Sengeti: BPS.

[5] Miles, Matthew B. and A. Michael Huberman, Analisis Data Kualitatif, Translated by Tjetjep Rohendi Rohidi. Jakarta: Universitas Indonesia Press, 1992.

[6] Bridgman, Peter dan Glyn Davis. The Australian Policy Handbook. Crows Nest: Allen and Unwin, 2004.

[7] Suharto, Edi, Membangun Masyarakat Memberdayakan Rakyat. Bandung: PT. Refika Aditama, 2010.

[8] Schiller, Bradley R., The Economic of Poverty and Discrimination, New Jersey: Pearson Education, Inc, 2008. 